\title{
Relationship between the Finnish Education and Teachers' Professional Development in the Perspective of Contemporary Challenges: Selected Aspects
}

So, imagination is the capacity to think of
things as possibly being so; [...] it is not dis-
tinct from rationality but is rather a capacity
that greatly enriches rational thinking

(Egan, 1992, p. 43)

\begin{abstract}
This article presents the relationship between the Finnish educational change in schools (the Finnish Reform Movement), selected aspects of teachers' professional development and context of educational thinking influenced by John Dewey's pedagogy. The successful change of schools “calls for a 'new professionalism' in which teachers' work is based on research-based, outcomes-oriented, data-driven and team focused at the same time as it is globalised, localised and individualised, with lifelong professional learning the norm for the specialist in school education" (Caldwell, 2003, p. 8). In this light, the article presents an overview of in-service training of teachers, cooperative learning and teachers' autonomy in schools in the context of teachers' professional development.
\end{abstract}

\section{Keywords:}

John Dewey’s pedagogy, the Nordic Model of Social Democracy, teacher professional development, teachers' autonomy in schools, in-service training of teachers, cooperative learning, equity in educational system

1 Faculty of Theory of Education, Department of Comparative Pedagogy, University of Łódź, Poland. 


\section{INTRODUCTION}

In the article, I am going to find out the relationship between the Finnish educational change, represented by the Finnish Reform Movement, teachers' professional development and John Dewey's pedagogy. The article presents an overview of the selected aspects of teachers' professional development. It acknowledges what is embodied in such documents as: in-service training of teachers, cooperative learning, and teachers' autonomy in schools. My one week Erasmus visit in 2017 helped me not only use the library sources of the University of Eastern Finland but also discuss with academics at this university the importance of using such sources.

\section{RESEARCH QUESTIONS AND METHODOLOGY}

In order to present the relationship between the Finnish educational change in schools and selected aspects of teachers' professional development, I formulated the following research questions: 1) what is the relationship between the Finnish educational change and teachers' professional development?; 2) What are the strengths of John Dewey's pedagogy in teachers' professional development?; 3) What is the role of teachers' professional development in the success of Finnish education?; 4) Does educational change contribute to teachers' better working conditions?

The main component of my study was an analysis of documents, especially those parts covering teaching content, which are applicable to all schools in Finland. As I mentioned previously, analysis of the documents began with a review of the literature on teachers' professional development. I employed the problem method, along with critical discourse analysis including the study of documents concerning teachers' professional development. I collected data concerning specific areas of "macro-themes of discourse" (Wodak \& Krzyżanowski, 2008, p. 156). The problem method derives from an educational phenomenon which is placed in time and related to society. From this perspective, it is necessary to contrast different views, regularities, and principles.

Discourse analysis was conducted using meanings which were usually contextual. In this light, this article uses discourse: not only language and its meanings, but also conventions and codes which are typical of particular societies and anchored in their cultures and history (Hammersley, 2013). Moreover, discourses are "social texts [...]; particular signifying practices of a given group [that] are 
both constituted by and constitutive of the discursive field in which members of the group live and function” (Elbaz, 1990, p. 15).

In this article I aimed at using primary rather than secondary sources, appearing in different places and at different times. Moreover, in this research I took the validity and reliability of the documents into consideration. Credibility and accuracy appeared to represent the next challenge. I chose representative documents and analysed the meanings presented in the documents along with their intended and perceived contexts. Scott (1990) presented a way of understanding documents "hermeneutically, according to four criteria (authenticity, credibility, typicality and meaning)”.

The most important step appeared to be analysis of primary materials accessed at the library at the University of Helsinki: National Core Curriculum for Basic Education 2014 and Basic Education Act 1998. After that, I took into consideration secondary sources of experts' studies: Krokfors et al. (2015), Niemi (2014a, 2014b), Ahtee, Lavonen, \& Pehkonen (2007), Hämäläinen, Hämäläinen, \& Kangasniemi (2015), Hargreaves \& Fullan (1992), Hargreaves, Halász, \& Pont (2008), Jyrhämä \& Maaranen (2012), Livingston \& Shiach (2010), Oikkonen et al. (2007), Rajakaltio (2014), and Salminen \& Annevirta (2016).

The next step was the choice of materials for final analysis. This research used sample materials which were the most representative and which provided the greatest support for the article. Analysis of documents was intended to focus equally on documents emphasising "the constructive mechanisms contained in the arguments, ideas, or concepts” (Rapley, 2007, p. 194). Furthermore, it was necessary to understand and then describe "the trajectory of all of these modern ideas, practices and identities that are currently taken for granted” (Wodak \& Krzyżanowski, 2008, p. 205).

\section{THE NORDIC MODEL OF SOCIAL DEMOCRACY AND EQUALITY}

We need to move toward a communicative democracy (McLaren, 1998, p. 364)

The Nordic Model of Social Democracy helps to understand pragmatic aspects of teacher professional development in Finland. The first educational reform in Finnish educational system started in November 1963, but the Parliament approved the 1968 School System Act a bit later. The teachers were asked how to reform the system of education. Moreover, there were asked questions how to unify the old educational system into the new one. 
On the other side, the Finnish old class society started to collapse between 1960s and 1970s. There was observed the attack of the youth generation on traditional Finnish values like home, religion, and fatherland. The young generation wanted democratization of education in Finland. Finnish society had the main aim to change education into successful one. Nordic countries, among them Finland, have been willingly involved in the development of social security. They introduced "dynamic economy with small wage differences" (Brandal, Bratberg, \& Thorsen, 2013, p. 11) and this model is almost totally resilient to changes in the economic situation.

The Nordic Model is based on a combination of "collective risk sharing and openness to globalization. There is mutually supportive interaction between these two elements: collective risk sharing helps make globalization acceptable to citizens, by facilitating adjustments that allow the economy to benefit from changing markets and to raise productivity and incomes” (Andersen et al., 2007, p. 14). The Nordics used the market economy, the egalitarian ambitions of the welfare state and actions to lead competition successfully. There is omnipresent interaction of security and flexibility and social trust not only among citizens, but in public institutions, too.

Finns reinvented educational theoretical and methodological basics of education and set up the new rules in conception of learning and conception of knowledge. These times they introduced a true equity in educational system. The most significant goal of educational equity in Finland is to develop an equal educational capacity for all students to be motivated to finish secondary education. The Nordic way of thinking takes into consideration all children and teenagers in need to support their educational development. Regardless of children's place of residence, their gender and family social status schools prepare the same principles to enhance the equality of educational opportunities.

\section{EQUALITY IN THE EDUCATION OF THE NORDIC MODEL OF SOCIAL DEMOCRACY}

Equality involves not only the particular rights and duties of people (Espinoza, 2007, p. 345) but their indistinguishable conflict over social power. Furthermore, it is also connected to the power of particular language in the process of building the social reality (Englund, 2005). "The notion of equality is not only a tool for linguistic description; it also evaluates and creates different educational realities and various instruments for their implementation” (Englund \& Quennerstedt, 
2008, p. 717). In this light, it makes sense to mention how educational equity phenomenon is represented in Finnish society. "Because school learning is strongly influenced by children's family background and associated factors, equity of outcomes requires that schools are funded according to real needs to cope with these inequalities" (Sahlberg, 2015, p. 149).

On the other side, there is a specific relationship, "as when John Dewey (1916) insisted that educational experience provided the bridge between 'self' and society, between self-realization and democratization” (Pinar, 2004, p. 13). In these circumstances, the presented relationship between the subjective and the social circles curriculum becomes a finished conversation or a political process. Consequently, development of curriculum involves leadership of public intellectual. Moreover, as Bruner (1960/1977) observed: “one of the places in which this renewal of concern has expressed itself is in curriculum planning for the elementary and secondary schools”. All crises in security of a particular country are "displaced" in the process of curriculum planning.

\section{JOHN DEWEY'S PEDAGOGY IN FINNISH EDUCATION}

John Dewey's philosophy of education was first mentioned in the process of acceleration of Finnish success in education. In Deweyan philosophy, democracy was not the destiny of humankind or an inevitable social state: "democracy will stand or fall with the possibility of maintaining the faith and justifying it by works" (Dewey, 1939/2003, p. 153). The way how democracy exist is related to people's way of believing that this is a real possibility. Moreover, it is worth to mention that only individual person can conduct or modify it to achieve success. "We have advanced far enough to say that democracy is a way of life. We have yet to realize that it is a way of personal life and one which provides a moral standard for personal conduct” (Dewey, 1939/2003, p. 156).

According to Sahlberg (2015, p. 167), it is "understandable that the pragmatic, child-centered educational thinking of John Dewey has been widely accepted among Finnish educators”. On the other side, Dewey's pedagogy is widely influenced on research-based education of teachers in Finnish universities. At the departments of education, future teachers are taught useful instruction to support pedagogical principles which are indispensable at schools. Having a pedagogical autonomy, universities in Finland prepare "a detailed and often biding strategy for improving the quality of teacher education programs” (Sahlberg, 2015, p. 116). 
As a result, Finnish universities are at the highest level according to advancement in international standards (Oikkonen et al., 2007). Finnish higher education is socially perceived as an effective and innovative. Universities use not only research-based teacher education, they involve in their curriculum studies such directions as cooperative learning, problem-based learning and reflective school practice to influence directly on personal development of teachers.

\section{RESEARCH-BASED TEACHER EDUCATION AS A DIRECTION IN DEVELOPMENT OF FINNISH TEACHERS}

The educational theories, research-based teacher education, research methodologies and everyday teaching practice are the main directions of teachers' professional development. Consequently, curricula of teacher education aggregate the basics of educational thinking and the set of educational methodologies to build more exceptional ways of teaching. Firstly, Finnish students are able to design, conduct and present the most original, outstanding research not only in theory but in practice of education, too. Secondly, a practical training at schools is a key part of the university study of future teachers in Finland. According to Sahlberg (2015, p. 117), "all teachers as professionals are able to understand teaching holistically and improve their work continuously". In this light, it is indispensable to mention about key elements of research-based teacher education in Finland.

Teachers are obliged to have a deep and wide knowledge about the most advanced research in their subjects of teaching. They have to understand the theoretical basics of a new research to use them practically in their classrooms. Research-oriented attitude in teachers' everyday teaching activities are related to teachers' open-mindedness and positive approach to teaching. Moreover, teachers' duty is to design conclusions which are based on varied sources used during their lessons. Finally, they are obliged to create the critical attitude to recent research and their practical observations during lessons. To sum up, the widely tailored teacher education must be researched and improved (Sahlberg, 2015, p. 117).

It is undisputed that Finnish society "trust their teachers and heads of schools" (Suwalska, 2018, p. 275). Moreover, as a representative of the National Board of Education claims, "we trust the expertise of our principals and teachers. We respect that expertise and we try to understand what is happening in the everyday life of schools and what questions have to be worked with, and we try to combine that with issues, interests and needs of the future at the national level” (Hargreaves, Halász, \& Pont, 2008, p. 85). 


\section{IN-SERVICE TRAINING OF TEACHERS}

The memorandum of the Advisory Board for Professional Development of Education Personnel suggested the challenges and paths of teachers' development for the next years (Hämäläinen, Hämäläinen, \& Kangasniemi, 2015). The main aim of this document was to provide constant and systematic support for teachers' professional development. Moreover, the core values for teachers' professional development were prepared by the Finnish National Board of Education (FNBE) (Rajakaltio, 2014, p. 5). This document paid attention to teachers' life-long learning, to wide knowledge of teachers and research-based orientation. The document mentions about effective teaching and forecast of future competences in education. Finland pays attention to movement from in-service training days into longlasting projects which contribute to sustainable effects. FNBE (Rajakaltio, 2014) underlined the integrity of teachers training in context of evaluation, new knowledge creation and gradual teachers' competence development.

Education centers for teachers' in-service training are in most universities in Finland. The centers have main aim which is to improve teachers' critical thinking on their own work. The other aim is that teachers create small design-based research projects in which they acquire new competences. All in all, in-service training reinforces teachers' own professional development and well-being with a positive effect on students' learning and motivation. Research-based and research-informed orientation of pre-service teacher sustains education. Consequently, teachers' up-to-date and advance knowledge of pedagogy and of their subjects increases through in-service training.

\section{TEACHER PROFESSIONAL DEVELOPMENT IN FINLAND}

Teacher professional development (TPD) as a life-long process is defined differently in OECD countries. Researchers mainly underline the need to regard TPD as a "series of processes that occur when teachers are working in schools after their graduation from teacher education institutes” (Niemi, 2015, p. 2). The researchers focus not only on teachers' learning processes, but on school effectiveness and professional learning communities, too (Boyle, Lamprianou, \& Boyle, 2005; Stoll et al., 2006). New graduates from departments of teacher education in Finland and subject teaching programs look for school employment due to the fact that teaching is one of the most desired professions in Finland. As a result, many licensed graduates try to find out the balance between idealism of lecture hall and school reality. 
The European Commission in 2010 published a document which presents recommendations for teachers with the emphasis on the cooperation of European countries. The handbook document describes some recommendations for induction programs for beginning teachers. "The first stage concerns the preparation of teachers during initial teacher education, where those who want to become a teacher master the basic knowledge and skills. The second stage is the first independent steps as teachers, the first years of confrontation with teaching reality. This phase is generally called the induction phase” (European Commission, 2010, p. 3).

Induction of a new teacher into a first classroom's rules is up to each school and municipality governing these schools. They take into consideration new teachers' needs for induction or mentor them how to be responsible in teaching. According to Sahlberg (2015), advanced procedures and support systems for new teachers become part of mission in some schools. Also, there are schools where school principals or deputy principals or well-experienced teachers are responsible for induction of new teachers.

The directions of professional development of teachers in Finland are partly included in the words of Anthony Mackay, who said: "If we want collaborative leadership, we need to have a collaborative system" (The Trade Union of Education in Finland, OAJ, 2019). There is the highest level need to find out collaborative leadership, which meets the contemporary challenges of the Finnish society. OAJ claimed, in this light, that there is need to build up collaborative school culture, too. Moreover, OAJ sees the need to continue life-long learning.

According to the Basic Education Act, which was introduced in 2010, "pupils are provided with general, enhanced or regular support in learning and attending school. OAJ has studied how the legislative reform has affected the work of education and training personnel and the support received by learners" (The Trade Union of Education in Finland, OAJ, 2019). It is essential that persons with a low level of education, and "even the ones without education, as well as all those at work including other working age people should have a possibility to improve continuously their level of basic skills” (The Trade Union of Education in Finland, OAJ, 2019).

In presented context, it is worth to write that the significance of teacher training was mentioned by many researchers (Conway et al., 2009, Livingston, 2012). According to Schwille and Dembélé (2007), there is a need to understand how teachers acquire indispensable capacity to teach and how the process of continuing professional development (CPD) of teachers is designed by themselves.

Moreover, Livingston and Shiach (2010) claim that the first stage of the professional development of students should help them to identify and explore their per- 
sonal attitudes in learning and teaching through discussions with other students and teachers who conduct their courses. Researchers like Livingston and Shiach (2010) or Niemi highlight that the main parts of "development of an inquiry and reflective approach during initial teacher education should be part of a continuing process where teachers evaluated their own learning and planned their on-going professional learning needs throughout their careers” (Niemi, 2015, p. 281). Critical inquiry approach and many questions empower future teachers with their own responsibility for the speed of their CPD and its influence on their professional careers.

Theory and practice are integral parts of teacher education programs and are part of academic studies in Finland. Teaching practice has three main parts: "orientation, intermediate practicum, and advanced practicum, which expand student teachers’ responsibilities” (Jyrhämä \& Maaranen, 2012). Teacher training schools, usually close to universities, supervise students' practice. They enhance students to work as reflective teachers who are critical practitioners.

\section{THE DIRECTIONS OF PERSONAL DEVELOPMENT OF FINNISH TEACHERS IN THE PERSPECTIVE OF CURRICULUM CHANGES}

In the 2000 curriculum for Basic Education (Basic Education Act 1998) the principles, values, and conception of learning are presented first, followed by the separate presentation of subject-specific objectives and contents. Moreover, in this document we read about definitions of the core curricula with its objectives, contents and criteria for evaluation. Furthermore, there are observed the evaluation criteria of the subjects taught, but they also accentuate the need to check how knowledge is structured (Vitikka, 2009, p. 271). In main part of the curriculum there are presented the factors which regulate the basic education and create "the pedagogical will” or “the spirit” (Vitikka, 2009, p. 168). There are also mentioned "the principles of basic education such as its values, conception of learning, learning environment, operational culture, teaching methods and working approaches” (Salminen \& Annevirta, 2016, p. 391). On the other side, this parts of the core curriculum exemplify how basic education will be achieved.

What is more, in the main part of the 2010 curriculum change, there were significantly redefined not only the teaching methods, but working approaches, too. It is especially seen in the context of definition of "general support for learning and special-needs education” which was changed in the Basic Education Act (642/2010) to "learning and schooling support". As a consequence, it explains that "support should be put into practice in schools as general support (the first tier of support), 
intensified support (the second tier of support) or special support (the third tier of support) according to pupils’ needs” (Salminen \& Annevirta, 2016, p. 391).

In this light, it is significant to write about pedagogical thinking in the process of teaching planning, which straightly contributes to pedagogical practices and their relations to students' learning. There is a curriculum written in 2010 (Finnish National Board of Education, 2010) that is supposed to diversify working approaches and teaching methods, which should be appropriate to varied subjects and situations at schools. Moreover, teachers are obliged to guide not only the entire group of students, but individual student, too. Furthermore, "schools must provide all pupils with the necessary knowledge and skills for a changing society and a more complicated environment” (Vauras, 2004, p. 30).

The curriculum change demands not only new methods and working approaches but it also changes "problem solving, working and interaction, self-knowledge and responsibility, participation and influencing, as well as expression and manual skills” (Salminen \& Annevirta, 2016, p. 392). The working approaches in Finnish education must promote communication and information technology skills. In this light, the duty of the Finnish teachers is to select methods. According to J. Bruner (1996, p. 116), "a curriculum is like an animated conversation on a topic that can never be fully defined”. On the other side, teachers in Finland using working methods should develop pupils' skills "for learning strategies and for acquiring, applying and evaluating information” (Salminen \& Annevirta, 2016, p. 392).

\section{COOPERATIVE LEARNING}

The idea of cooperative learning has been incorporated into Finnish schools since 1970s, and then it was slightly used to upgrade the level of students from varied educational background. Consequently, the 1994 curriculum reform introduced permanently cooperative learning into Finnish schools. Moreover, the 1994 curriculum reform introduced school freedom in ways of introducing curriculum in school and during lessons. There were used ideas of constructivism and teachers got the recommendations to include the elements of cooperative learning into their teaching. Step by step, teachers have acquired new ways of introducing cooperative learning during their lessons.

According to the National Core Curriculum for Basic Education 2014, shared responsibility for the school day is manifested in the organization of school work (2016, p. 36). The document underlines the achievement of educational goals and fulfilment of the mission of primary education. Consequently, the school work 
contributes to preconditions of students' well-being, enjoyment of safe school day and well-working cooperation among parts of school community.

The document stresses (National Core Curriculum..., 2016, pp. 37-38) three ways of how to achieve safety of learning environments and well-being of all school participants. The school confirms that students gain experiences of wide cooperation in their classes or groups. Students play a significant role in planning multifaceted learning modules. They develop school activities, the learning environment, participate in evaluation and school cooperation.

In this light, the National Core Curriculum for Basic Education 2014 puts an emphasis on cooperation with students' homes. The organization of education supports this cooperation and ensures that students obtain instructions, guidance and help related to their needs. Cooperation between home and school conducts the students' healthy growth and development, promotes their well-being and safety. The school and teachers manage students' homework and lead the responsibility for instructions of tasks.

In regards of internal cooperation and cooperation with other parties, the National Core Curriculum for Basic Education 2014 underlines close cooperation among the school staff and other adults, it demands planning, introduction of multidisciplinary models, support, evaluation and the implementation of students' welfare. Cooperation with other schools helps at the point of transition of students from primary education into another school. To ensure the learning path of students, basic schools cooperate with early childhood, pre-primary education, upper-secondary and vocational schools. Basic schools cooperate with libraries, youth and sports centres, police, companies, organizations and museums.

\section{TEACHERS' AUTONOMY IN SCHOOLS}

Finnish teachers are truly leaders due to the fact that they prepare their own curriculum with coordination and acceptation of local education authorities. As a result, teachers are the authors of needed guidance and indispensable regulations which contribute to their students' success. According to Sahlberg (2015), there are four primary reasons to employ teachers' responsibility in schools in context of their autonomy.

Firstly, educational policy in Finland prioritizes creative teaching to personalize students' learning at schools. It is done to reinforce students' abilities and skills, not to follow standards of teaching. Secondly, it is significant to mention that teachers' school practice and their thinking about teaching must contain cur- 
riculum, teaching and learning. Teachers do not have to pay attention to testing their students, as it exists in Poland, England, and the USA. Thirdly, in Finland, it is socially accepted that student's progress depends on their school; it is not related to external assessment or tests. Teachers are responsible for students' assessments and their progress. Unhealthy competitions among schools do not support students' learning; it forces schools to set up the rules of the narrow curriculum and teaching to tests. School-based evaluation is more valuable in context of students' preparation to job market and to life.

On the other hand, in Finnish schools there is used the strategy of students' assessment which is based on the principle of diversified evidence in which test-based performance data are just part of the whole (Sahlberg, 2015, p. 123). Furthermore, the municipalities design their own practices including quality and assurance of particular school's needs. In this light, it makes sense to mention that the only moment when standardized tests are used is the National Matriculation Exam at the age of 18 or 19 in Finland. According to Sahlberg (2015, p. 31), it is a stressful period of life, when students must study to test, which only narrows the school curriculum.

Autonomy in Finnish schools means to arrange time, to schedule working day with 15 minutes break after 45 minutes of lesson. If we compare the amount of hours which students spend on learning it is less in Finland than in OECD countries. Finnish teachers have more time to improve their school work and to work together. Moreover, teachers have more time for planning and exchange of their own curriculum, which is regularly updated. Teachers save time for experimenting with teaching methods, collaboration with parents and communities in which they live. In Finland, rankings between schools do not exist. Matriculation exams are exceptions because these results are presented.

\section{SUMMARY}

This article revealed the relationship between the Finnish educational change and teachers' professional development. The article presented the strengths of John Dewey's pedagogy in teachers' professional development which starts at university level. Universities and schools use research-based teacher education, curriculum studies, cooperative learning, problem-based learning and reflective school practice to influence directly on professional development of teachers. As a result, Finnish higher education in context of teachers' professional development is perceived as effective and innovative. 
There is no doubt that this article is an overview of in-service training of teachers, present in most universities in Finland. In-service training reinforces teachers' own professional development and well-being with a positive effect on students' learning and motivation. It improves their critical thinking on their own work and helps to create small design-based research projects to acquire new competences, up-to-date and advance knowledge of pedagogy and of their subjects through in-service training.

As a result of my analyses, I conclude that cooperation is a key part of teachers' professional development. The analysed document, i.e., the National Core Curriculum for Basic Education 2014, underlines close cooperation among the school staff and adults, which demands planning, introduction of multidisciplinary models, support, evaluation and the implementation of students' welfare. Cooperation with other schools helps at the point of transition of students from primary education into another school. To ensure the learning path of students from basic schools, teachers cooperate with early childhood, pre-primary education, upper-secondary and vocational schools. Basic schools teachers cooperate with libraries, youth and sports centres, police, companies, organizations and museums.

Similarly significant are the implications of my findings about teachers' autonomy. It means that Finnish teachers are truly the leaders who prepare their own curriculum. This educational change contributes to teachers' better working conditions and prioritizes creative teaching. Teachers do not have to pay attention to testing their students. It is socially accepted that student's progress depends on their school; it is not related to external assessment or tests. Teachers are responsible for students' assessments and their progress. Unhealthy competitions among schools do not support students' learning; it forces schools to set up the rules of the narrow curriculum and teaching to tests.

To sum up, the article presents the educational change in Finland in the context of teachers' personal development. Finland has built the standards to which other countries could aspire. It is undisputed that Finnish teachers follow the same values about vision of education and they set up their work in a cooperative way. As a result, teachers in Finland prepare thoughtful global citizens who are able to overcome obstacles of the contemporary world.

\section{References}

Ahtee, M., Lavonen, J., \& Pehkonen, E. (2007). The Evaluation of the Finnish Success Story. In: E. Pehkonen, M. Ahtee, \& J. Lavonen (Eds.), How Finns Learn Mathematics and Science (pp. 266-272). Rotterdam-Taipei: Sense Publishers. 
Andersen, T.M., Holmström, B., Honkapohja, S., Korkman, S., Söderström, H.T., \& Vartiainen, J. (2007). The Nordic Model: Embracing Globalization and Sharing Risks. ETLA B, The Research Institute of the Finnish Economy, No. 232. Helsinki: Taloustieto Oy.

Basic Education Act 628/1998 (1998). Retrieved from: https://www.finlex.fi/fi/laki/kaannokset/1998/en19980628.pdf (access date: 21.02.2019).

Boyle, B., Lamprianou, I., \& Boyle, T. (2005). A Longitudinal Study of Teacher Change: What Makes Professional Development Effective? Report of the Second Year of the Study. School Effectiveness and School Improvement, 16(1), pp. 1-27. DOI: 10.1080/09243450 500114819.

Brandal, N., Bratberg, Ø., \& Thorsen, D.E. (2013). The Nordic Model of Social Democracy. Basingstoke: Palgrave Macmillan.

Bruner, J.S. (1960/1977). The Process of Education. Cambridge, MA: Harvard University Press.

Bruner, J.S. (1996). The Culture of Education. Cambridge, MA: Harvard University Press.

Caldwell, B.J. (2003). Mission Impossible? A Strategic View of Efforts to Lead the Transformation of Schools. Paper Presented at $6^{\text {th }}$ World Convention of the International Confederation of Principals, UK, Edinburgh.

Cohen, L., Manion, L., \& Morrison, K. (2018). Research Methods in Education (8 ${ }^{\text {th }}$ Ed.). New York: Routledge.

Conway, P.F., Murphy, R., Rath, A., \& Hall, K. (2009). Learning to Teach and Its Implications for the Continuum of Teacher Education: A Nine-Country Cross-National Study. Report Commissioned by the Teaching Council, Ireland. DOI: 10.13140/RG.2.1.1551.2724.

Dewey, J. (1939/2003). Freedom and Culture. In: J.A. Boydston (Ed.), The Later Works of John Dewey, 1925-1953. Vol. 13: 1938-1939 (pp. 63-188). Carbondale: Southern Illinois University Press.

Egan, K. (1992). Imagination in Teaching and Learning. Chicago: University of Chicago Press.

Elbaz, F. (1990). Knowledge and Discourse: The Evolution of Research into Teachers' Thinking. In: C. Day, M. Pope, \& P. Denicola (Eds.), Insights into Teachers’ Thinking and Practice (pp. 15-42). Basingstoke: Falmer.

Englund, T. (2005). The Discourse on Equivalence in Swedish Education Policy. Journal of Education Policy, 20(1), pp. 39-57. DOI: 10.1080/0268093042000322829.

Englund, T., \& Quennerstedt, A. (2008). Linking Curriculum Theory and Linguistics: The Performative Use of "Equivalence” as an Educational Policy Concept. Journal of Curriculum studies, 40(6), pp. 713-724. DOI: 10.1080/00220270802123938.

Espinoza, O. (2007). Solving the Equity-Equality Conceptual Dilemma: A New Mode for Analysis of the Educational Process. Educational Research, 49(4), pp. 343-363. DOI: 10.1080/00131880701717198.

European Commission (2010). Developing Coherent and System-wide Induction Programmes for Beginning Teachers: A Handbook for Policymakers. EC Staff Working Document SEC (2010) 538 final. Brussels: Directorate-General for Education and Culture.

Halinen, I. (2018). The New Educational Curriculum in Finland. In: M. Matthes, L. Pulkkinen, Ch. Clouder, \& B. Heys (Eds.), Improving the Quality of Childhood in Europe. Vol. 7 (pp. 75-89). Retrieved from: http://www.allianceforchildhood.eu/files/Improving_the_quality_of_Childhood_Vol_7/QOC\%20V7\%20CH06\%20DEF\%20WEB.pdf (access date: 28.02.2020). 
Hämäläinen, K., Hämäläinen, K., \& Kangasniemi, J. (Eds.) (2015). Paths to Continuing Professional Development: The Challenges and Future of State-Funded Professional Development of Education Personnel. The Memorandum of the Advisory Board for Professional Development of Education [in Finnish; Abstract in English]. Publications of Ministry of Education and Culture 2015:10. Helsinki, Finland.

Hammersley, M. (2013). What Is Qualitative Research? London: Sage.

Hargreaves, A., \& Fullan, M.G. (1992). Understanding Teacher Development. London: Cassell.

Hargreaves, A. Halász, G., \& Pont, B. (2008). The Finnish Approach to System Leadership. In: B. Pont, D. Nusche, \& D. Hopkins (Eds.), Improving School Leadership. Vol. 2: Case Studies on System Leadership (pp. 69-109). Paris: OECD.

Henderson, J.G., \& Kesson, K.R. (2001). Curriculum Work as Public Intellectual Leadership. In: K. Sloan, \& J.T. Sears (Eds.), Democratic Curriculum Theory \& Practice: Retrieving Public Spaces (pp. 1-23). Troy, NY: Educator's International Press.

Jyrhämä, R., \& Maaranen, K. (2012). Research-Orientation in a Teacher’s Work. In: H. Niemi, A. Toom, \& A. Kallioniemi (Eds.), Miracle of Education: The Principles and Practices of Teaching and Learning in Finnish Schools (pp. 97-112). Rotterdam: Sense Publishers.

Krokfors, L., Kangas, P., Kopisto, K., Rikabi-Sukkari, L., Salo, L., \& Vesterinen, O. (2015). Learning. Creatively. Together. Educational Change Report 2016. Helsinki: University of Helsinki, Department of Teacher Education, Faculty of Behavioural Sciences.

Livingston, K. (2012). Approaches to Professional Development of Teachers in Scotland: Pedagogical Innovation or Financial Necessity? Educational Research, 54(2), pp. 161-172. DOI: 10.1080/00131881.2012.680041.

Livingston, K., \& Shiach, L. (2010). A New Model of Teacher Education. In: A. Campbell, \& S. Groundwater-Smith (Eds.), Connecting Inquiry and Professional Learning (pp. 33-45). London: Routledge.

McLaren, P. (1998). Revolution and Reality. An Interview (with C. Borg, P. Mayo, \& R. Sultana). In: W.F. Pinar (Ed.), Curriculum: Toward New Identities (pp. 354-376). New York: Garland.

National Core Curriculum for Basic Education 2014 (2016). Helsinki: Finnish National Agency for Education, Juvenes Print.

Niemi, H. (2014a). Teachers as Active Contributors in Quality of Education: A Special Reference to the Finnish Context. In: D. Hung, K.Y.T. Lim, \& S.S. Lee (Eds.), Adaptivity as a Transformative Disposition for Learning in the $21^{\text {st }}$ Century (pp. 179-199). Singapore: Springer.

Niemi, H. (2014b). Purposeful Policy and Practice for Equity and Quality - A Finnish Case. In: S.K. Lee, W.O. Lee, \& E.L. Low (Eds.), Education Policy Innovations: Levelling Up and Sustaining Educational Achievement (pp. 103-121). Singapore: Springer.

Niemi, H. (2015). Teacher Professional Development in Finland: Towards a More Holistic Approach. Psychology, Society, \& Education, 7(3), pp. 279-294. DOI: 10.25115/psye. v7i3.519.

Oikkonen, J., Lavonen, J., Krzywacki-Vainio, H., Aksela, M., Krokfors, L., \& Saarikko, H. (2007). Pre-service Teacher Education in Chemistry, Mathematics and Physics. In: E. Pehkonen, M. Ahtee, \& J. Lavonen (Eds.), How Finns Learn Mathematics and Science (pp. 49-68). Rotterdam-Taipei: Sense Publishers. 
Pinar, W.F. (2004). What Is Curriculum Theory? Mahwah-New Jersey-London: Laurance Erlbaum Publishers.

Rapley, T. (2007). Analiza konwersacji, dyskursu i dokumentów. Warszawa: PWN.

Rajakaltio, H. (2014). Towards Renewing School: The Action Model of the School Development - Integrating In-Service-Training and the Development Process. Reports and 2014:9. Reports and reviews 2014:9. Helsinki, Finland: The Finnish National Board of Education. (in Finnish)

Sahlberg, P. (2015). Finnish Lessons: What Can the World Learn from Educational Change in Finland. New York: Columbia University.

Salminen, J., \& Annevirta, T. (2016). Curriculum and Teachers’ Pedagogical Thinking When Planning for Teaching. European Journal of Curriculum Studies, 3(1), pp. 387-406.

Schwille, J., \& Dembélé, M. (2007). Global Perspectives on Teacher Learning: Improving Policy and Practice. Paris: UNESCO, International Institute for Educational Planning.

Scott, J. (1990). A Matter of Record: Documentary Sources in Social Research. Cambridge: Polity Press.

Slattery, P., \& Rapp, D. (2002). Ethics and the Foundations of Education: Teaching Convictions in a Postmodern World. Boston: Allyn \& Bacon.

Suwalska, A. (2017). English Educational Policy: Contemporary Challenges in a Historical-Comparative Context. Łódź-Kraków: Wydawnictwo Uniwersytetu Łódzkiego, Wydawnictwo Uniwersytetu Jagiellońskiego.

Suwalska, A. (2018). Wysoki poziom zaufania do pracy nauczycieli w Finlandii po 1970 roku. Studia z Teorii Wychowania, 9(3), pp. 273-287.

Stoll, L., Bolam, R., McMahon, A., Wallace, M., \& Thomas, S.M. (2006). Professional Learning Communities: A Review of the Literature. Journal of Educational Change, 7(4), 221-258. DOI: 10.1007/s10833-006-0001-8.

The Finnish National Board of Education. (2010). Basic Education in Finland - How to develop the top ranked education system? Presentation at Building Blocks for Education: Whole System Reform- Conference, September 13-14, Toronto, Canada.

The Trade Union of Education in Finland, OAJ (2019, March 15). Retrieved from: https:// www.oaj.fi/en/news/blogs/ollin-blogi/2019/we-need-a-shared-vision-of-a-better-futureand-a-long-term-plan-for-funding-education/ (access date: 13.05.2019).

Vauras, M. (2004). Oppimiskäsitys. In: E. Vitikka, \& O. Saloranta-Eriksson (Eds.), Uudistuva perusopetus. Näkökulmia opetuksen ja opetussuunnitelman kehittämiseen [Renewing Basic Education: Perspectives on the Development of Teaching and Curriculum] (pp. 28-47). Jyväskylä: Gummerus.

Vitikka, E. (2009). Opetussuunnitelman mallin jäsennys. Sisältö ja pedagogiikkakokonaisuuden rakentajana [Structuring Curriculum Design: Content and Pedagogy Constructing the Whole]. Kasvatusalan tutkimuksia 44. Helsingin yliopisto. Väitöskirja. Helsinki: Suomen kasvatustieteellinen seura ry.

Vitikka, E., Krokfors, L., \& Hurmerinta, E. (2012). The Finnish National Core Curriculum: Structure and Development. In: H. Niemi, A. Toom, \& A. Kallioniemi (Eds.), Miracle of Education: The Principles and Practices of Teaching and Learning in Finnish Schools (pp. 83-95). Rotterdam: Sense Publishers.

Wodak, R., \& Krzyżanowski, M. (Eds.) (2008). Qualitative Discourse Analysis in the Social Sciences. New York: Palgrave Macmillan. 